УДК 530.145.6:621.37

\title{
ВХОДНЫЕ ИМПЕДАНСНЫЕ ХАРАКТЕРИСТИКИ БАРЬЕРНЫХ СТРУКТУР
}

\author{
ГИНДИКИНА М. А., ВОДОЛАЗСКАЯ М. В., НЕЛИН Е. А. \\ Национальный технический университет Украины \\ «Киевский политехнический институт», \\ Украина, Киев, 03056, пр-т Победы 37
}

\begin{abstract}
Аннотация. Рассмотрены универсальные особенности входных импедансных характеристик. Получены аналитические выражения для входных импедансных характеристик типичных волновых барьерных структур. Приведены зависимости входного импеданса от энергии для квантово-механических структур и частоты - для электромагнитных и акустических структур. Найдены дополнительные к известным условия резонансного прохождения и резонансной локализации волн в барьерных структурах
\end{abstract}

Ключевые слова: входной импеданс; двухбарьерная структура; двухъямная структура

\section{ВВЕДЕНИЕ}

Слоистые барьерные структуры используются во многих научных и технических приложениях и составляют основу наноэлектроники. В них особую значимость имеет резонансное прохождение, в особенности туннелирование волн с коэффициентом прохождения, равным единице [1]. Поскольку при обычном туннелировании коэффициент прохождения чрезвычайно мал, сочетание режимов резонансного и обычного туннелирования в устройствах обработки сигналов обеспечивает максимальное отношение сигналов в полосах пропускания и подавления.

К важным резонансным эффектам в волновых структурах относится также резонансная локализация волн, происходящая в дисперсивной среде, ограниченной с двух сторон полубесконечными реактивными средами. Термины «дисперсивная» и «реактивная» среда соответствуют [2]. В реактивной среде волновое число мнимое, в результате волна не рас- пространяется, ее амплитуда экспоненциально, без рассеяния энергии, уменьшается.

Как резонансное прохождение, так и резонансная локализация обусловлены формированием в структуре резонансной стоячей волны.

В различных технических областях широко используют двухбарьерные структуры (ДБС). Квантово-механическая ДБС с резонансным туннелированием электронов [1] базовая структура наноэлектроники. ДБС лежит в основе резонансного туннельного диода с $N$-образной вольт-амперной характеристикой и отрицательным дифференциальным сопротивлением [3]. Резонансное туннелирование сквозь ДБС используется для электромагнитных $[4,5]$ и акустических [6] волн. На основе ДБС конструируются оптические микрорезонаторы [1,7].

Значительный интерес представляет квантово-механическая двухъямная структура (ДЯС) с двухъямным потенциалом [8,9]. ДЯС используется для моделирования квантово-механических систем с двумя состояниями 